\title{
NOTAS SOBRE IDEALISMO ABSOLUTO
}

Eduardo Luft

SÍNTESE - O objetivo deste artigo é apresentar o Idealismo Absoluto - em parte como o próprio Hegel o havia concebido - como Filosofia Crítica, que busca superar a cisão entre as dimensões empirica e transcendental do saber. Procura ainda levantar objeçōes contra o modo de justificaçăo dos princípios no "sistema do dever ser" e alertar para o risco de retorno a uma ontologia dogmática.
ABSTRACT - The intent of these article is to show the absolute idealism as critical philosophy. This philosophy wants to overcome the dualism between the empiric and transcendental dimension of knowledge. The author wants also to make objections against the way of justification of the principles in the "system of the should be" and call attention to the risk of retuming to dogmatic ontology.

\section{O Idealismo Subjetivo: Kant e Fichte}

1. Um dos objetivos básicos do Idealismo Absoluto preconizado por Hegel é superar a oposição não conciliada entre a dimensão empírica' e transcendental do saber, característica do Idealismo kantiano. Esta tarefa, Hegel a compartilha com Fichte. No fundo, o Idealismo kantiano não consegue superar a dicotomia inerente à posição da consciência ordinária: o sujeito se relaciona externamente com os objetos de seu saber, pois seus conteúdos são provenientes de fora (matéria da sensibilidade), sendo unificados primeiramente pela intuição (através das formas puras da sensibilidade) e posteriormente pelo entendimento (juizos baseados em categorias).

Mestrado no Curso de Pós-Graduação em Filosofia da PUCRS.

1. O uso do termo empírico está vincado, em todo o presente artigo, na problematização do dualismo kantiano entre conhecimento empírico e conhecimento puro. O conceito de empírico não será necessariamente referido a um conhecimento vinculado à realidade externa (fenomênica), mas também será usado como expressão daquele momento contingente, singular, inerente a toda a forma de racionalidade oniabrangente. A tese final deste artigo, de que há uma dose ineliminável de empiricidade mesmo na Lógica de Hegel, não vincula de modo algum o Idealismo Absoluto a uma espécie de realismo disfarçado. De fato, não se diz com isto que a Lógica nos traria um vínculo imediato entre o pensamento e a realidade - o que seria absurdo no contexto da obra - mas sim que permanece uma dose de contingência mesmo neste âmbito de uma filosofia da linguagem e do pensamento.

\begin{tabular}{|l|l|l|l|l|l|} 
VERITAS & Porto Alegre & v. 42 & $\mathrm{n}^{2} 4$ & Dezembro 1997 & p. 891-912 \\
\hline
\end{tabular}


2. Esta característica da filosofia kantiana traria consigo dois problemas centrais: a pressuposição ao mesmo tempo necessária e arbitrária da coisa em $\mathrm{si}^{2} \mathrm{e}$ a incapacidade de justificar o modo de ligação entre entendimento e sensibilidade, ou a própria capacidade de síntese, pois a apercepção originária permanece no sistema kantiano como uma incógnita. ${ }^{3}$ Estes dois problemas levam: o primeiro ao dogmatismo e o segundo a um déficit sistemático do pensamento kantiano.

3. A Doutrina da Ciência de Fichte quer justamente dar conta destes dois déficits do kantismo, recuperando o projeto de uma Filosofia da consciência em novas bases. . Fichte procurará sanar o vazio posto entre consciência empirica e transcendental (ou pura) e arquitetará o seu sistema tendo por fundamento a atividade produtora do eu absoluto. $\mathrm{O}$ eu só é absoluto porque nada permanece fora dele, nada o condiciona; tudo o que há na consciência (todo o saber) é dele derivado e nele justificado.

Este projeto só pode ser efetivado a partir da subsunção do eu empírico no eu transcendental, na ruptura da dicotomia básica herdada do kantismo. Como nos diz Hegel, no escrito sobre a Diferença dos Sistemas de Filosofia de Fichte e de Schelling (1801): "Se provamos que a consciência empirica é fundada completamente na consciência pura e não é meramente condicionada por ela, assim a sua oposição é superada; isto se o esclarecimento é completo, ou seja, se não mostramos apenas uma identidade parcial da consciência empírica e da consciência

2 As discussões em torno do conceito de coisa-em-si tiveram sua origem já nas primeiras investigações da Filosofia pós-kantiana, através de Reinhold, e viriam a ser a tônica dos grandes debates do Idealismo Alemão. Cf́. N. Hartmann, A Filosofia do Idealismo Alemão, Lisboa: Calouste Gulbenkian, 1976, p. 15 ss.

3 Segundo Kant, "a unidade sintética da apercepção é o ponto mais elevado, ao qual precisa estar ligado todo o uso do entendimento, e mesmo toda a lógica e, com ela, toda a filosofia transcendental [...]" (Kritik der reinen Vernunft, Hamburg: Felix Meiner, 1990, B134). Por outro lado, Kant também nos diz: "Mas como seja possivel esta propriedade particular de nossa sensibilidade, ou do nosso entendimento e da apercepção originária que repousa no fundamento do entendimento $e$ de todo o pensar, isto nāo se pode solucionar nem responder, porque nós precisamos dela para realizar qualquer resposta para todo o pensamento de objetos" (Prolegomena zu einer jeden künftigen Metaphysik, Köln: Könemann, 1995, §36, p. 89). Este caráter de irreflexividade, que impede o pensamento kantiano de indagar criticamente por seus próprios fundamentos últimos é a característica que fará desta forma de criticismo um novo dogmatismo, e será um dos pontos centrais nas críticas dos filósofos posteriores do Idealismo Alemão. Hegel procurará sanar este déficit de fundamentação através da circularidade negativa do Conceito. Sobre a falta de uma fundamentação reflexiva em Kant, cf. os argumentos de V. Hösle, Hegels System, Hamburg: Felix Meiner, 1988, p. $16 \mathrm{ss}$, e de M. A. de Oliveira, para quem Kant "[...] não foi capaz de distinguir entre uma fundamentação dedutiva e uma demonstração propriamente reflexiva" (Sobre a Fundamentação, Porto Alegre: Edipucrs, 1993, p. 29).

t Isto naturalmente não impede que, em suas linhas gerais, o sistema fichteano se coloque como continuador do kantismo, particularmente em sua pretensāo de fundar uma filosofia critica. O que Fichte denunciará em Kant - e da mesma forma pensará Hegel - é justamente a sua incapacidade de levar às últimas consequêências o projeto criticista. Sobre o antidogmatismo das filosofias de Kant e Fichte e a superação fichteana do resíduo dogmático ínsito no kantismo, cf. M. Guerolt, "L'Antidogmatisme de Kant et de Fichte", in: Études sur Fichte, Paris: Aubier-Montaigne, 1974, p. 17. Guerolt destaca o vínculo estrito entre razão critica e liberdade em Fichte e Kant, e a luta desta tradição do Idealismo contra o sistema de Espinosa e sua tendência ao dogmatismo e ao necessitarismo. 
pura. A identidade é apenas parcial quando um lado da consciência empirica permanece não determinado pela consciência pura [...]". .

O eu só é absoluto - e o próprio Idealismo só é, para Hegel, Idealismo Absoluto - se na própria consciência empírica não permanece qualquer resíduo não posto pelo eu. A razão teórica permanece para Fichte refém da oposição sujeito/objeto, pois o eu só é idêntico a si mesmo enquanto diferente de (determinado por) um não-eu que lhe é contraposto. Esta oposição deveria ser superada, no entanto, pela razão prática - fundamento da teórica - pois para esta a oposição não é algo imposto como sua condição externa de possibilidade, mas resultado, produto da ação originária do eu. Daí por que a proposição principal da razão prática, em Fichte, nos diz: "o eu se põe como determinando o não-eu".?

\section{O Idealismo Absoluto: de Fichte a Hegel}

4. Hegel não rejeita este programa de Fichte; pelo contrário, assume-o de modo pleno: só será verdadeiramente absoluto aquele Idealismo que resolver a oposição entre eu empírico e eu transcendental. As críticas de Hegel não dizem respeito aos objetivos críticos da filosofia fichteana com relação a Kant, mas à sua incapacidade de realizá-los plenamente: "A especulação do sistema exige a superação da oposição, mas o sistema mesmo não a supera; a sintese absoluta, para a qual o sistema existe, não é eu = eu, mas eu deve ser eu"."

Como se explica este "dever ser" da identidade do eu consigo mesmo? Não era a identidade do eu consigo mesmo enquanto ser (e não dever ser) justamente a base do sistema de Fichte? Se notarmos as peculiaridades da passagem da razão teórica para a razão prática em Fichte, logo veremos que esta identidade é, primeiramente, um problema: na razão teórica, ela só é enquanto o eu é determinado pela contraposição do não-eu. Há uma exterioridade entre eu e não-eu na razão teórica que a impede de realizar a identidade plena consigo. A proposta de solução deste dilema terá seu lugar na razão prática, mas aqui também há um resíduo de exterioridade e a dicotomia do eu consigo mesmo não poderá ser sanada: o eu só é ativo (razão prática) enquanto o seu ato de autoposição é ao mesmo tempo ato de posição constante da oposição insita na razão teórica.' A infinitude, a ab-

- Hegel, "Differenz des Fichteschen und Schellingschen Systems der Philosophie" (1801), in: Jenaer Schriften, Werke, v. 2, Frankfurt am Main: Suhrkamp, 1990, p. 52.

- Devemos analisar justamente se esta "ausência de resíduo" é possivel, se o sistema hegeliano foi capaz de superar todo o elemento de empiricidade inerente ao saber. A meu ver, o Idealismo Absoluto só é capaz de realizar-se plenamente a partir de um processo oposto àquele realizado por Hegel: não a reificação da razăo pura, mas a dissolução da unilateralidade do saber transcendental, e a demonstração de seu vinculo último com um momento ineliminável de empiricidade.

7 FICHTE, "Grundlage der gesammten Wissenschaftslehre (1794)", in: Fichtes Werke, Berlin: Walter de Gruyter, 1971, §5, p. 248.

\& HEGEL, Differenz, op. cit., p. 50.

- Cf. o que nos diz a respeito N. Hartmann: "A conduta, a ação, o agir não são uma produção ilimitada mas sim um agir sobre qualquer coisa. A sua atividade é aspiração, e aspirar é vencer. Ora bem, só se pode vencer onde existe uma resistência, só se pode aspirar a algo onde exista qualquer coisa que resista à aspiração, quer dizer, um obstáculo [...]. A oposição é, portanto, condição da aspiração. $\mathrm{O}$ eu absoluto tem de tomar-se teórico para ser prático; tem de criar primeiro 0 mundo dos objetos em cuja resistência há-de ser ativo" (op. cit., p. 78). 
solutidade do eu prático não é, mas deve ser, pois toda a realização da autoposição do eu só é enquanto esta ação é finitizada na oposição inerente à razão teórica. Ou seja, a razão prática só é enquanto põe e repõe constantemente a dicotomia de eu e não-eu, característica da razão teórica, numa tarefa infinita: "O eu teórico é finito, assim como o objeto posto por ele. Mas o eu prático deve ser infinito; o seu objeto é um objeto ideal infinito".

Daí por que, para Hegel, a oposição sujeito/objeto não pode ser resolvida no interior do sistema fichteano, pois justamente a instância que seria capaz de resolvê-la não faz mais do que reinstaurá-la infinitamente.

5. "A unidade é forçada numa identidade apenas relativa; a identidade, que deve ser absoluta, é incompleta. O sistema tornou-se um dogmatismo - um realismo que põe de modo absoluto a objetividade, ou um idealismo que põe de modo absoluto a subjetividade - algo oposto à sua filosofia [...]"." "O Idealismo dogmático obtém a unidade do princípio porque ele nega de modo geral o objeto e põe um dos opostos - o sujeito em sua determinidade - como o absoluto, assim como o dogmatismo enquanto materialismo puro nega o subjetivo"."2

Estas críticas feitas por Hegel contra o resultado dogmático do projeto fichteano e seu Idealismo Subjetivo são centrais para decifrar o sentido e a tarefa da Fenomenologia do Espírito, a obra que coloca Hegel no centro das grandes discussões do Idealismo alemão. Por que o dogmatismo em Fichte?

No parágrafo 32 da Enciclopédia, Hegel dirá que "a Metafísica tornou-se dogmatismo porque ela precisava aceitar, pela natureza das determinações finitas, que, de duas afirmações opostas, [...] uma era verdadeira, a outra falsa". ${ }^{3}$ De modo geral, o dogmatismo refere-se, para Hegel, à incapacidade de superar as oposições inerentes ao saber: incapacidade de superar o caráter excludente das oposições e pensá-las em seu aspecto correlativo. Mas, neste caso específico, o que está em jogo é aquela oposição entre eu transcendental e eu empíico, pois é ela que está na base do caráter excludente da relação de sujeito e objeto.

O resultado deste dogmatismo - tanto no sentido fichteano, da supremacia do sujeito sobre o objeto, ou no dogmatismo realista, com a supremacia inversa - é a aceitação necessária dos pressupostos não problematizados da consciência ordinária. $\mathrm{E}$ um destes pressupostos, talvez o mais fundamental, trata de uma exterioridade irredutível do objeto com relação ao sujeito; em Kant, esta dimensão aparece na origem desconhecida da "matéria" da sensibilidade, na idéia de coisa em si - a base dogmática, porque injustificada e injustificável, do sistema kantiano. 0 Idealismo teria de arcar neste caso inevitavelmente com um resíduo não idealista em seu âmago," daí ele ser incapaz de cumprir com o sentido mais originário do

\footnotetext{
N. HARTMANN, op. cit., p. 79.

HEGEL, Differenz, op. cit., p. 48.

Id., ibid., p.61.

HEGEL, Enzyklopädie der philosophischen Wissenschaften, Werke, v.8, Frankfurt am Main: Suhrkamp, §32, p. 98.

n Cf. N. HARTMANN, op. cit., p. 16: "Seja como for que se compreenda o ser-em-si neste grande conceito enigmático (coisa-em-si), esse ser-em-si foi e continua a ser um elemento anti-idealista, de fato o elemento anti-idealista que permaneceu no limiar do idealismo, sendo impossivel desconhecê-lo sem o fazer desaparecer".
} 
verdadeiro Idealismo: a criticidade reflexiva que não põe nada fora da ação negativa do pensamento.

6. O projeto de Hegel é radicalizar o Idealismo critico kantiano, rejeitando o resíduo dogmático que havia deixado suas marcas mesmo na filosofia de Fichte. Podemos perceber já uma breve antecipação da Fenomenologia - a ser publicada seis anos após, ou seja, em 1807 - no próprio escrito sobre a Diferença: "O Absoluto está construído desde o ponto de vista transcendental, mas não do ponto de vista fenomênico [...]"; ; “o absoluto precisa pôr-se no fenômeno mesmo, ou seja, não destrui-lo, mas construí-lo na identidade". ${ }^{18}$ Só será Idealismo Absoluto aquele Idealismo que, ao abarcar o empirico em si, é ao mesmo tempo capaz de superálo. Esta será a tarefa principal da Fenomenologia.

7. Podemos dizer que, na Fenomenologia e na Lógica, já está contido em germe o sistema de Hegel como um todo. Digo "na Fenomenologia" porque esta, a meu ver, não pode ser considerada apenas como introdução ao sistema, a ser elaborado independentemente daquela. O próprio Hegel repetirá mais de uma vez na Lógica que a Fenomenologia é o lugar de justificação" (ao menos primeira) do Conceito (o princípio organizador do sistema). Só se o absoluto é apresentado primeiramente como pressuposto da consciência fenomênica, a oposição entre empírico e transcendental pode ser sanada. A falência deste projeto seria a confirmação de que o absoluto permanece condicionado por um elemento que ao mesmo tempo é por ele pressuposto e a ele inacessivel (o retorno à cisão sujeito/objeto e a todos os problemas que terminaram por resultar no conceito forçado de coisa em si).

A Fenomenologia trata do descenso do filósofo ao nível da consciência ordinária (ou natural, conforme Husserl), indagando-a pela verdade de seu saber. Deverá ela provar que o saber natural pressupõe o saber absoluto, que a Fenomenologia pressupõe a Lógica. Mas haveria também uma pressuposição da Lógica com relação à Fenomenologia? Ora, se o momento primeiro de justificação do Conceito é a Fenomenologia parece que deveriamos dar uma resposta positiva a esta pergunta.

Mas a Lógica deve ser entenđida, em sua pretensão última, não apenas como a aceitação da Fenomenologia (ou do saber absoluto, ápice desta) como o seu pressuposto inicial, mas também como a obra que tem a pretensão de demonstrar que este pressuposto pode ser integralmente posto na autoposição da idéia absoluta (o fim da Lógica). O pressuposto inicial - o próprio absoluto - é revelado ao fim como imediaticidade posta, pressuposição posta: "Os momentos do método especulativo são: a) o começo, que é o ser ou imediato; isto por um motivo sim-

HEGEL, Differenz, op. cit., 50.

Id., ibid., p. 48.

" Cf. HEGEL, a introduçăo da Wissenschaft der Logik, Werke, v. 5, Frankfurt am Main: Suhrkamp, 1990, p. 43: "O Conceito da ciência pura e sua dedução (deduktion) está pressuposto no presente tratado, pois a Fenomenologia do Espinito não é nada mais do que a sua dedução"; "mas o Conceito da Lógica mesma está na introdução como resultado de uma ciência anterior, e com isto já está dado aqui como pressuposto" (id., p. 57); cf. ainda "Com o que deve se fazer o início da ciência", o texto sem número colocado logo ao início da Lógica, id., p. 67ss: "A Lógica tem, portanto, a ciência do espirito fenomênico como sua pressuposição, a qual contém e apresenta a necessidade e com isto a prova da verdade do ponto de vista do saber puro assim como a sua me-diação". 
ples: por ser o começo. Mas, para a idéia especulativa, o ser é o autodeterminar da idéia mesma, o qual, como negatividade absoluta ou movimento do Conceito, julga e põe-se como o negativo de si mesmo. O ser, que aparece para o começo como mera afirmação abstrata, é muito mais a negação, o ser posto, ser mediato em geral e ser pressuposto". "Este jogo entre pressuposição e posição procura provar a possibilidade de autonomização absoluta da Lógica com relação à Fenomenologia.

Esta pretensão hegeliana expressa justamente uma tentativa de superar aquela antiga dicotomia entre empírico e transcendental que, como vimos, terminaria levando a um idealismo ou a um realismo dogmáticos. Se a Lógica consegue ao mesmo tempo pressupor o fim da Fenomenologia (e, com isto, pelo modo de articulação do sistema hegeliano, pressupor também toda a Fenomenologia, inclusive seus momentos de mais extrema empiricidade) e negar toda a dimensão empírica inerente àquela, tendo como resultado a autoposição transcendental pura da idéia (o absoluto) sobre si mesma, então o Idealismo pode agora ser chamado Idealismo Absoluto: o círculo se fecha sobre si mesmo.

Mostraremos ao final deste artigo uma outra interpretação possivel deste Idealismo Absoluto preconizado por Hegel. De qualquer forma, parece claro que esta eliminação da imediaticidade do absoluto em seu caráter inicial na Lógica só pode ser realizada com a ativação do momento negativo ou dialético da racionalidade.

8. Hegel guarda marcas aqui das pretensões básicas do saber moderno, na tentativa de elevar a Filosofia à ciência. ${ }^{19}$ Como nos diz R. Bubner, ${ }^{\infty}$ Hegel é um espirito influenciado pelo ideal cientificista ${ }^{21}$ da modernidade. A Filosofia pode ser considerada ciência em dois aspectos: primeiro, ela é capaz de ir além das ciências particulares em seu nivel de criticidade, conseguindo superar todas as pressuposições (toda a imediaticidade) graças à sua negatividade última; em segundo lugar, ela é capaz de uma autofundamentação positiva, de uma superação desta negatividade, através da circularidade absoluta da idéia.

Como sabemos, no parágrafo 79 da Enciclopédia Hegel faz o pensamento especulativo superar o momento negativo da dialética, fornecendo um fundamento seguro para a Filosofia. A partir deste ponto, as relações entre dialética e sistema parecem se tornar problemáticas, pois de fato: como é possivel, na circularidade perfeita da idéia - na resolução plena de todas as contradições - manter-se o momento negativo e crítico do pensar dialético?

18 HEGEL, Enzyklopädie, op. cit., §238, p. 390.

19 É neste contexto que se insere a famosa passagem da Fenomenologia, onde Hegel propōe que a Filosofia deixe de ser um mero amor ao saber, para ser saber efetivo. Cf. Phänomenologie des Geistes, Werke, v.3, Frankfurt am Main: Suhrkamp, p. 14.

zo R. BUBNER, Dialektik als Topik, Frankfurt am Main: Suhrkamp, 1990, p. 88.

" Falo aqui de um modelo de ciência fundamentada numa concepção dedutivista e apriorista do saber, que tinha a pretensão, tão bem representada pela Ética de Espinosa, de fundar todo o saber humano em principios racionais, de onde seria deduzido todo o saber verdadeiro possivel. Talvez o grande erro de Hegel tenha sido aquele de, ao mesmo tempo, detectar os limites (externos) do saber formal e a sua superação possivel, mas não se precaver contra os limites (imanentes) da racionalidade dialética que cuidaria de plenificar esta superação. 
Não é por nada que esta obra fundamental que é a Fenomenologia termina sendo afastada por Hegel, em sua maturidade, de instância de introdução ao sistema, ficando relegada na Enciclopédia a estágio particular da Filosofia do Espíito Subjetivo. Hegel pensa numa autonomização absoluta da Lógica com relação a qualquer momento de empiricidade. Se a Fenomenologia continua a pressupor a Lógica, esta última não pressupõe nada além de si mesma. Esta confiança cada vez maior na possivel autonomização da Lógica com relação a qualquer momento de empiricidade levará Hegel a considerar cada vez mais supérflua a condição da Fenomenologia como introdução ao sistema.

As pretensões de Hegel apontam para esta fundamentação absoluta positiva que o círculo fechado sobre si mesmo "consolida". Teriamos então um transcendental que se purifica radicalmente de qualquer momento de empiricidade. Daí a ênfase na característica de prova, de demonstração, inerente à argumentação dialética, muitas vezes proclamada por Hegel.

9. Já sabemos hoje em dia das três objeções centrais contra um projeto de fundamentação absoluta do tipo descrito acima: círculo vicioso, regresso ao infinito, dogmatismo. ${ }^{2}$ Uma das objeções mais recentes aponta para um regresso ao infinito na argumentação hegeliana. ${ }^{n}$ Acredito que a fundamentação proposta por Hegel terminaria caindo pelo menos em duas das objeções do trilema de Münchhausen: círculo vicioso e dogmatismo. Círculo vicioso porque a reflexão absoluta da idéia, ao superar de vez todas as contradições, suprimiria também o processo de "dedução" das categorias: no fim da Lógica terminariamos simplesmente recolocando no argumento de prova (no grande monólogo da Lógica) aquilo que antes deveria ter sido provado: a idéia absoluta. Dogmatismo porque uma tal reflexão, ao eliminar a possibilidade de surgirem novas contradições, terminaria dispensando justamente aquele momento que sustenta a criticidade do método dialético, substituindo-o pela afirmação de uma certeza absoluta e indemonstrada: a "evidência" da idéia absoluta. ${ }^{2}$

n

Cf. L. Puntel, para quem "o experimento dialético se apresenta então como processo lógico na forma da iteração de uma autonegação que sempre reinicia novamente: o resultado é um regresso ao infinito" ("Lässt sich der Begriff der Dialektik klären?", Journal for General Philosophy of Science, 27, 1996, p. 137).

24

A esta objeção parece estar suscetivel a interpretação de V. Hösle referente ao conceito de contradição em dialética (baseada num artigo de W. Wieland, "Bemerkungen zur Anfang von Hegels Logik", in: R-P Horstmann (org.), Seminar: Dialektik in der Philosophie Hegels, Frankfurt am Main: Suhrkamp, 1989, p. 194ss). Para Hösle, a contradição surge em todas as categorias da Lógica porque estas contêm implicitamente mais do que explicitamente é afirmado; é justamente neste déficit de explicitação de sentido que reside a contradição dialética. Mas, quando chegamos à idéia absoluta, categoria de desfecho da Lógica, o sentido será explicitado e a contradição terá sído sanada. Cf. V. Hösle, op. cit., p. 203: “[...] Quando se explicita tudo (all) o que está implícito no conceito de ser, chega-se à idéia absoluta". A outra alternativa a esta tese seria afirmar que, de fato, podem surgir futuramente novas contradições, ainda não previstas em nossa elaboração conceitual. Mas isto não resolveria o dilema, pois a pergunta ressurgiria: é possivel encontrar o desfecho definitivo, o círculo perfeito da idéia sobre si mesma ou não? Se surgirem novas contradições, o seu surgimento é fruto de um lapso subjetivo do pensador (daquele que constrói a lógica) - que não explicitou todo o sentido que deveria ter sido explicitado - ou é conseqüência do elemento de contingência inerente à própria lógica: o déficit se refere, como diriam os franceses, à Lógica (à obra) ou ao lógico? A pretensão de V. Hösle de conceber a dialética hegeliana como uma espécie 
Poderia ser objetado contra estes argumentos críticos que a fundamentação em Hegel possui peculiaridades, e a principal delas é seu caráter reflexivo: enquanto uma argumentação dedutiva é incapaz de uma fundamentação última, uma argumentação reflexiva é disto capaz. ${ }^{\star}$ De qualquer modo, a idéia de uma reflexão absoluta, que dispensasse toda a mácula de empiricidade, cairia nas duas objeções citadas acima: círculo vicioso e dogmatismo. No entanto, o argumento de M. A. de Oliveira se dirige, não no sentido do texto hegeliano, mais em sua reformulação a partir dos argumentos de V. Hösle e, particularmente, no modo de fundamentação da pragmática transcendental de K.-O. Apel. Veremos os déficits desta corrente argumentativa a partir da análise do sistema do dever-ser que adere em parte a este tipo de fundamentação (veremos depois por que "em parte").

10. A meu ver, a dialética só pode ser recuperada na sua contraposição contra o sistema hegeliano e sua tendência ao fechamento. Ela deve ser recuperada no centro de um Idealismo Absoluto como Filosofia crítica, que procure levar até o fim a sua tarefa originária de superar a cisão entre os momentos empírico e transcendental da razão. O idealismo hegeliano estrito seria melhor designado como Idealismo Objetivo, ${ }^{2}$ que pensa numa autonomização da Lógica de qualquer momento de empiricidade, e cuja conseqüência última é a eliminação do momento subjetivo inerente a todo o filosofar. Mas, antes de tratarmos do Idealismo Absoluto como Filosofia Crítica, comentaremos uma outra alternativa de sistema, que procura levar em conta o momento de empiricidade no coração do Absoluto, e tenta com isto superar as mazelas do hegelianismo ortodoxo: o sistema do dever ser.

\section{Crítica ao modo de fundamentação dos princípios no sistema do dever ser}

11. O projeto de sistema do dever ser, ${ }^{n}$ elaborado por C. R. Cirne-Lima, atenta para esta necessidade de realizar plenamente o projeto hegeliano de conciliação da substância de Espinosa com o eu livre de Kant. Compreende ainda a importância, para realização deste projeto, da superação da dicotomia entre empírico e transcendental.

Mas, de saída, sentimos neste projeto uma falta: a ausência de qualquer momento semelhante ao ocupado pela Fenomenologia no sistema de Hegel. Somos

de método dedutivo (ao modo fichteano) e a Lógica como fundamento de um saber apriórico nâo deixa outra alternativa do que a defesa da primeira opção. De fato, como a Lógica permaneceria com uma pretensão de saber apriórico se tivesse em seu interior um momento ineliminável de empiricidade?

๙ Cf. os argumentos de M. A. de Oliveira em Sobre a Fundamentação, op. cit., particularmente p. 68ss. Para o autor a pragmática transcendental supera os déficits da fundamentação, por exemplo, da filosofia kantiana, justamente por contar com um modo de fundamentação reflexiva desconhecida por Kant.

* Cf. V. HÖSLE, "Begründunsfragen des objektiven Idealismus", in: Philosophie und Begründung, Frankfurt am Main: Suhrkamp, 1987, p. 212ss.

n Cf. especialmente as obras Sobre a Contradiçăo, Porto Alegre: Edipucrs, 1996, 2. ed. e Dialética para Principiantes, Porto Alegre: Edipucrs, 1996, de C. R. Cime-Lima. 
lançados aos três princípios sem qualquer introdução. ${ }^{\circledR}$ Se encararmos a Fenomenologia como primeiro momento de justificação do Conceito, temos aqui um déficit claro de fundamentação. Por outro lado, surge imediatamente o receio de estarmos aqui presos a uma nova tentativa de autonomização da Lógica de qualquer momento de empiricidade: isto não nos levaria a recair numa (ou mais) das três objeções do Trilema?

12. No entanto, não devemos nos precipitar: é clara a intenção de Cirne-Lima de reservar um momento de empiricidade no âmago de seu projeto de sistema. Este seria garantido por um dos três princípios de seu sistema, o princípio da diferença (2). Cirne-Lima apresenta ainda outros dois princípios fundantes: princípio da identidade (1) e princípio da coerência (3). Pergunta: "Está certo: estamos aqui perante os três princípios, mas por que aceitá-los como princípios?" Ou seja, voltamos ao problema da fundamentação.

Em primeiro lugar, o projeto de sistema do dever ser não contém nada semelhante a uma justificação dialética que trataria de revelar a imbricação mútua dos princípios, terminando numa boa circularidade (que só é possível a meu ver preservando um momento de empiricidade). Não: os princípios são justapostos, e justificados - quando o são - de maneira autônoma.

O princípio de identidade, segundo Cirne-Lima, é imediatamente autojustificado, pois aqui se trata de uma tautologia $\mathrm{A}=\mathrm{A}$. Como discípulos de Hegel, poderíamos de saída contestar esta autojustificação, pois toda a tautologia supõe vinculado a ela um conteúdo que é externo a qualquer consideração de ordem formal. Assim, antes de afirmarmos A = A, temos de ter A (A deve estar posto); para termos A como posto, devemos determiná-lo diferenciando-o de um B qualquer; portanto, o princípio de identidade parece remeter ao princípio da diferença como seu oposto complementar.

13. Poderíamos pensar, então, que o princípio da diferença daria conta de uma fundamentação de si mesmo e do déficit de fundamentação inerente ao princípio de identidade. Mas, para surpresa nossa, o princípio da diferença é considerado por Cirne-Lima como não fundado: trata-se de um mero fato, um dado com o qual se deve lidar sem se perguntar pela sua justificação, ou simplesmente afirmando que esta é, aqui, impossivel. Neste ponto aparece uma séria objeção: como se pode pôr um fato como principio de todo o ser e pensar sem ao mesmo tempo submetê-lo à reflexão, ou seja, sem trazê-lo à criticidade do pensar e sua pergunta pela justificação? O único modo possivel de realizar isto é submetê-lo, sim, ao pensar, mas justificá-lo com um mero argumento de autoridade: eu decido que isto seja assim. A este momento de decisão inerente à fundamentação última positiva está vinculado aquele dogmatismo tão bem denunciado por $\mathrm{H}$. Albert. ${ }^{\text {}}$

2 Esta dúvida foi esboçada também por M. A. de Oliveira, em colóquio realizado na PUCRS, no primeiro semestre de 1997.

2 Cf. H. AL.BERT, op. cit., p. 49: “Com isso o princípio da fundamentação suficiente do modelo clássico de racionalidade, que pretendia originalmente unir a verdade e a certeza, portanto, possibilitar o conhecimento seguro, conduziu, em última análise, à evidência de que, para se alcançar certeza absoluta, ter-se-ia que sacrificar o realismo e, com ele, a idéia de uma verdade com conteúdo, pois, como se sabe, enunciados analiticos são por certo "necessariamente" verdadeiros, porém nada dizem sobre a realidade. A aplicaçāo radical do principio da fundamentação suficiente $e$, 
Não devemos tentar remediá-lo obscurecendo este momento dogmáticodecisionista próprio desta forma de fundamentação, mas denunciá-lo como o ônus da tentativa de uma fundamentação última positiva.

14. Poderíamos, por fim, - mas isto seria expressamente rejeitado por CirneLima, e veremos por que - supor que o princípio de coerência cuidaria de uma justificação final dos três princípios, pois ele resolveria ao mesmo tempo o seu problema de justificação, cuidando ainda daquele déficit de fundamentação já denunciado nos outros dois princípios. Se isto fosse possivel, chegariamos àquela concepção de dialética tão bem apresentada por M. A. de Oliveira: "Platão distingue entre conhecimento da dialética, o paradigma do conhecimento propriamente filosófico, cuja especificidade é chegar a um princípio não condicional (arché anypóthetos, $510 \mathrm{~b} 6$ e ss), isto é, ao que não pode mais ter pressupostos, por ele mesmo ser o pressuposto de tudo. A tarefa da dialética consiste precisamente, superando todos os pressupostos, por ela mesma ser o pressuposto de tudo. [...] 0 conhecimento próprio da Filosofia não é um conhecimento que é conhecimento que apela para hipóteses fora dele mesmo, mas um conhecimento que é conhecimento do conhecimento (episteme epistemes)". ${ }^{30}$ A ausência de pressupostos seria a marca da fundamentação positiva (autofundamentação) que revela uma das faces da pretensão científica da dialética.

Mas, como Cirne-Lima pretende fundamentar o princípio de coerência? Este princípio nos diz que contradições não devem existir, e não que não existam. Ora, uma afirmação contraditónia é uma afirmação falsa; e a afirmação falsa por excelência é aquela do cético que nega toda a verdade possivel: "Não existe nenhuma proposição que seja verdadeira"." Ao provar a inconsistência desta afirmação, estaríamos provando a consistência da proposição contraditória: "Ao menos algumas proposições são verdadeiras"; e, por fim, através de argumento transcendental, chegariamos à proposição: "A verdade, a princípio, existe". A certeza da existência de algumas proposições verdadeiras e a certeza da dissolução (inconsistência) da proposição cética provaria, assim, a validade do princípio de não-contradição (ou principio de coerência). De fato, se a afirmação do cético não fosse refutada, o principio de coerência não poderia ser justificado, pois não teríamos conseguido demonstrar sequer a incoerência da mais flagrante das proposições contraditórias. O princípio estaria justificado não a partir de um método dedutivo (através do qual a fundamentação última seria inviável, como nos mostra M. A. de Oliveira), ${ }^{2}$ mas de um método reflexivo, também chamado de dialético porque passa inevitavelmente por um momento negativo mediador, ou seja, a refutação do cético.

Mas, poderíamos perguntar: qual o resultado de toda esta argumentação senão uma mera tautologia, ou seja, resultado algum (já que uma tautologia não é

implicitamente, de fundamentos seguros, conduz, portanto, à substituição do conhecimento pela decisão".

3o M. A. de Oliveira, Sobre a Fundamentação, op. cit., p. 19.

" Cirne-Lima, Sobre a Contradição, op. cit., p. 114.

32 Conforme M. A. de Oliveira, já Aristóteles "[...] teve consciência dos limites da fundamentaçāo através de inferência de um conhecimento de outros, isto é, de uma fundamentação dedutiva de conclusões" (Sobre Fundamentação, op. cit., p. 21-22). 
informativa)? Isto porque todo o argumento depende da aceitação dupla do cético de que:

a) o que vem a ser verdade;

b) verdade a princípio existe.

Ora, poderíamos retrucar, e por que não aceitar simplesmente uma certa definição de verdade - por exemplo, verdade lógica ou não-contradição - e a existência da verdade neste sentido? Podemos aceitar; mas, antes de começar o diálogo, o cético exigiria justamente aquilo que toda esta encenação quer realizar, ou seja, uma fundamentação do que vem a ser verdade e da possibilidade de sua existência. $\mathrm{O}$ argumento é na verdade circular (má circularidade), pois ao fim do processo estariamos simplesmente retomando a mesma concepção de verdade que ao início já nos gerava dúvida.

Este não seria o caso se desde sempre o discurso do cético transitasse no âmbito de aceitação dos principios. E é isto que Cirne-Lima pressupõe, seguindo a tradição da filosofia transcendental de Apel: toda a argumentação com sentido pressupõe pelo menos o princípio de não-contradição. Ao falar argumentativamente, o cético pressupõe este princípio. Mas, quando se faz uma separação entre fala argumentativa e não argumentativa, já se pressupõe de fato que há um âmbito não abrangido por princípios e que o cético deve passar daquele para este. Mas, justamente para realizar esta passagem, terímos que provar ao cético que esta diferença existe, que ela é possivel, que ela é justificada, ou seja, pediríamos para explicitar os princípios: circulo!

Mesmo se negássemos esta diferença entre fala argumentativa e não argumentativa (ou seja, conforme ou não conforme a certos principios racionais) - 0 que é por sinal absurdo, porque exigiria uma anulação de toda a dimensão potencialmente contraditória da língua, tornando ineficaz o próprio princípio de nãocontradição - ainda assim dependeriamos de uma decisão do cético de tomar a iniciativa de dizer algo. Esta decisão é inexplicável internamente ao argumento transcendental e todo o argumento deste tipo é ao mesmo tempo dependente desta decisão do cético: não temos de qualquer modo uma justificação última ou incondicionada.

15. O resultado desta argumentação crítica com relação ao modo de justificar os princípios primeiros-últimos de Cirne-Lima é, no fundo, o seguinte: o método transcendental - utilizado neste ponto por Cirne-Lima - é incapaz de uma justificação última, embora esta seja a pretensão de muitos de seus defensores. Esta refutação não é nada mais do que a confirmação da antiga idéia hegeliana que mostra os déficits da filosofia de Kant. A argumentação transcendental supõe um momento condicionante externo para realizar sua justificação: é inevitável a postulação de uma coisa em si que aparece frente ao sistema ao mesmo tempo como rejeitada (porque desconhecida, injustificável internamente ao sistema) e necessária para sua justificação, mesmo se nas considerações acima a "coisa desconhecida" seja o próprio cético, condenado a mera planta e ao mesmo tempo alçado a fundamento último de todo o sistema.

16. Mas este resultado já é antevisto, no fundo, por Cirne-Lima; isto por dois motivos: a) Cirne-Lima recusa-se a dar ênfase ao problema da fundamentação, 
preferindo a idéia de mosaico comro figura básica da argumentação filosófica; b) o próprio Cirne-Lima mostra, em Sobre a Contradição, através da idéia de "interligação do a priori e do a posteriori na dialética", a dependência de todo o argumento transcendental de um momento condicionante externo: "O método dialético e o método transcendental estão, neste exemplo, interligados e imbricados. $\mathrm{O}$ que é, nisto, contingente? Primeiro, a passagem não-necessária da proposição 1 para a proposição 2 . É perfeitamente possível ficar na proposição 1 , ou de maneira ingênua e dogmática, afirmando que ela é verdadeira, ou de maneira cética, dizendo que não se sabe o que é verdade e o que é falsidade".

Mas o problema é que justamente aqui não há uma imbricação de método transcendental e dialético, mas uma supremacia do primeiro. As conseqüências desta supremacia são aquelas já detectadas: a justaposição "analítica" (no sentido amplo em que Cirne-Lima utiliza este conceito) dos princípios não é negada, mas confirmada pelo terceiro princípio, que contém justamente justapostos e não integrados o momento empírico e o momento transcendental.

17. Este argumento pode ser usado por Cirne-Lima justamente para provar que o princípio 2 é não fundável, um mero estar dado, não podendo ser incorporado pelo principio 3. Mas, a meu ver, isto só provaria que de fato há um momento dogmático, não fundado, no projeto de sistema do dever ser.

18. Por fim, o sistema do dever ser não consegue superar a cisão entre os momentos empírico e transcendental do saber, que é justamente o grande desafio do Idealismo Absoluto defendido por Hegel. Seria preciso, incorporando o momento negativo da dialética, superar esta dicotomia originária do kantismo; este era, como vimos, o projeto hegeliano, que justamente através desta superação poderia também negar o caráter inconciliável de pensar (eu puro) e ser (coisa em si), que é apenas a contrapartida necessária daquela dicotomia entre eu empírico/eu transcendental.

\section{Idealismo Absoluto como Filosofia Crítica 1 - Sobre a "refutação" do ceticismo}

19. O resultado do que foi dito acima é: em primeiro lugar, o cético permaneceu não refutado e os princípios fundamentais (ou o princípio fundamental) da racionalidade permaneceram indemonstrados. Mas seria de se perguntar se 0 modo negativo de justificação do Conceito foi realmente esgotado. À primeira vista, esgotamos aqui dois modos de fundamentação: por um lado, a fundamentação positiva, que terminaria incorrendo numa (ou mais) das críticas do Trilema de Münchhausen; revelamos ainda que a justificação negativa, via argumento transcendental, revelou-se como uma mera tautologia. Não sabemos, no entanto, se de fato não haveria outra forma de justificação negativa e, mesmo assim, consistente. Aristóteles já havia reconhecido o caráter de indemonstrabilidade dos princípios primeiros últimos - como o princípio de não-contradição: se toda e qualquer demonstração depende da aceitação dos princípios, terminariamos inevitavelmente, ao tentar demonstrá-los, caindo num círculo. O próprio Aristóteles também havia

s Cime-Lima, Sobre a Contradiçäo, op. cit., p. 115. 
tratado de uma espécie de "demonstração" negativa, ou por refutação: "Mas pode-se demonstrar por refutação também a impossibilidade disto, desde que 0 adversário diga algo; e, se não diz nada, é ridículo tratar de discutir com quem não pode dizer nada, já que não pode dizê-lo; pois este, enquanto tal, é por isto semelhante a uma planta. Mas demonstrar refutativamente, digo que não é o mesmo que demonstrar, porque, ao demonstrar, pareceria pedir-se o que está no princípio [...]". ". Mas a perplexidade de Aristóteles neste ponto tem muito a nos dizer. Em primeiro lugar, uma "demonstração" por refutação não é propriamente demonstração. Logo a seguir Aristóteles procurará mostrar que todo o argumento por refutação depende da (é, portanto, condicionado pela) aceitação prévia pelo opositor do discurso com sentido. Aquele que ao mesmo tempo aceita uma argumentação com sentido, mas quer desfazer os princípios que justamente garantem esta argumentação, entra em contradição consigo mesmo. Mas este argumento, claramente, não prova coisa alguma, não nos informa nada, é uma mera tautologia, pois o discurso com sentido já desde sempre implica a aceitação (mesmo que implícita) dos principios. Como nos diz Aristóteles, "[...] o que concede isto já concedeu que há algo verdadeiro sem demonstração", ou seja, a aceitação da argumentação com sentido já é aceitação (sem demonstração) dos princípios. Em segundo lugar, como esta aceitação depende em última instância de uma decisão do cético, o filósofo não pode mais do que apontar para o ridículo da recusa ao diálogo racional: o cético terminaria reduzido à condição de uma planta. ${ }^{*} \mathrm{~A}$ ironia é o último recurso do filósofo diante da fragilidade das tentativas de justificação dos primeiros princípios.

20. O fato é que a tradição filosófica pouco explorou a via negativa efetiva de justificação: este caminho só é efetivo se o filósofo não simplesmente rejeita de saida toda a argumentação não conforme a principios, mas mergulha a fundo no universo cético. No entanto, pelo menos dois filósofos levaram a sério esta alternativa: Descartes e Hegel. Para Descartes, é a dúvida radicalizada que dará origem à justificação do cogito. Para Hegel, na Fenomenologia, só a passagem pelo caminho do desespero levará o espírito a superar a dicotomia entre sujeito e objeto e realizar a primeira instância de justificação do Conceito; assim como, na Lógica, só transitando pelo momento negativo-racional, pela contradição dialética, o pensar poderá realizar-se como idéia absoluta. Parece-nos, no entanto, que ambos os filósofos não levaram até o fim as conseqüências deste mergulho no ceticismo: Descartes termina por hipostasiar o cogito, desvinculando-o de sua origem cética, da própria atividade da dúvida - a evidência, como critério último do conhecimento verdadeiro, substituirá o processo certamente frágil da dúvida - e do mesmo modo Hegel procurará superar todo o momento dialético-negativo no caráter especulativo-puro do Conceito.

21. Mas tanto Descartes quanto Hegel nos ensinam ser inútil toda a tentativa de refutar o cético a partir de um campo que lhe é estranho e ao qual tentamos forçá-lo a aderir: Hegel sabia ser inútil a tentativa de superar a empiricidade ine-

Metafisica, Madrid: Gredos, 1987, 1006a 10-15.

36 Id. ibid., 1006a 25.

* Id. ibid., 1006a 15. 
rente à consciência natural hipostasiando uma esfera absoluta sobre ela - 0 eu puro, por exemplo - e convidando-a gentilmente ao convivio com o ar asfixiante da esfera meramente transcendental.

Precisamos descer à esfera do empírico, o que é o mesmo que juntar-se ao cético. Mas - pode objetar-se com razão - esta descida de Hegel não é efetiva, porque desde sempre ele já tem a certeza de que estamos descendo, e de que há, portanto, uma linha divisónia entre transcendental e empírico, e o lugar supremo do primeiro já está garantido." No entanto, a grandeza da dialética hegeliana é justamente não contentar-se com este postulado e encarar esta descida não como uma mera gentileza à consciência natural, mas como caminho inevitável do absoluto.

De qualquer forma, de acordo com os argumentos esboçados até aqui, não se trata mais de uma descida do transcendental ao empírico mas de uma queda, pois de fato o caráter incondicional do saber foi refutado através do fracasso da tentativa de imunizar o argumento transcendental do ceticismo. 0 resultado do argumento contra o cético foi exatamente o inverso do que se pretendia.

22. O único que pode resolver este dilema é aquele que compartilha do diálogo com o cético, não como seu oponente, mas como seu parceiro. A partir da queda da argumentação do nível transcendental ao empirico deveremos repensar a própria viabilidade desta distinção rigorista, cujas origens remontam à tentativa de Platão de imunizar os princípios filosóficos de qualquer horizonte cético. A divisão entre o mundo da normatividade pura, mundo das formas, e o mundo passivel de ser normatizado, mundo sensível, entre forma e conteúdo, é o núcleo originário especulativo que está na gênese da divisão moderna entre eu empírico e eu transcendental, entre os sujeitos singulares cuja percepção dos fenômenos é sempre singular e contingente, e o sujeito absoluto - eu transcendental - com seu entendimento universal e necessário dos fenômenos. Posta a crítica com relação a esta divisão entre empírico e transcendental, apresentada a carência do método transcendental em sua tentativa de fundar os principios do saber racional, esqueçamos momentaneamente esta pressuposição de duplicidade incontornável do saber e iniciemos um franco diálogo entre céticos.

23. O filósofo, destituído de sua supremacia, é o próprio cético, está no caminho do desespero e é neste contexto que se move o seu pensamento. O cético está calado e recusa a afirmar qualquer coisa que seja sobre o real, recusa-se a iniciar uma fala argumentativa, por temer que esta terminaria por levá-lo a aceitar certos princípios do discurso racional. O cético é uma planta, mas uma planta significativa, pois de fato a ação mesma de recusar-se a falar tem um sentido, assim como tem um sentido ético a minha simples recusa (sem qualquer fala explícita) a ajudar um outro ser humano que se encontre em perigo eminente. A atitude do cético nos diz algo: a própria recusa de qualquer diálogo.

Ao encontrar o seu companheiro assim calado, a primeira objeção do cético contra o cético seria: "Certo: derrotamos a pretensão absoluta do argumento transcendental, mas podemos conviver com o único pressuposto que ainda resiste:

( Cf. texto de E. Stein, em A Caminho de uma Fundamentação Pós-metafisica, Porto Alegre: Edipucrs, 1997, p. 9 ss. 
a decisão cética de abster-se de qualquer forma de discurso racional (entendido aqui apenas como discurso que busca justificar suas afirmações)? ${ }^{\text {? }}$ Esta atitude em si mesma não é o mais declarado dogmatismo? Não estamos aqui na maior das inconsistências, aquela que ao mesmo tempo levanta uma pretensão crítica geral, a nível prático e teórico (um ceticismo integral), e se agarra no dogma de uma decisão infundada a nível prático?”

24. Devemos primeiro explicitar que aqui dialogam, na verdade, duas formas diversas de ceticismo. $\mathrm{O}$ cético que neste diálogo é interrogado pertence a uma vertente cuja expressão mais intensa se encontra na chamada suspensão de juizo dos céticos pirrônicos ${ }^{3}$ e seus seguidores. A atitude de recusar-se a argumentar é sua marca fundamental: o pirrônico não afirma nem nega a suposta verdade de certas afirmações; simplesmente, se cala. O ceticismo pirrônico apresenta, no entanto, as suas limitações.

O problema fundamental daquele que decide pela suspensão de juízo é que sua decisão termina por reforçar o assim chamado calcanhar de Aquiles ${ }^{\text {to }}$ do ceticismo: as questões práticas. 0 ceticismo pirrônico é necessariamente um ceticismo pela metade, o avesso de um ceticismo integral: sua atitude de suspender o juízo soluciona o problema do cético no nivel teórico. De fato, como poderiamos refutar o cético se ele sequer afirma algo sobre algo? No âmbito teórico, o cético está aqui imune a toda a refutação. Mas esta imunidade teórica tem o seu preço: só se chega a ela às custas de uma atitude dogmática. Ele teve de aceitar uma dimensão de si mesmo - momento prático - como um dogma, para liberar a dimensão teórica para a crítica racional. De fato, o que ocorreria se o cético pirrônico colocasse em questão sua própria decisão de suspender o juízo, de não participar de qualquer diálogo racional? Neste caso, a sua decisão também entraria em questão, o cético retornaria ao nível de uma argumentação racional e teria de justificar por que esta decisão é melhor ou mais conveniente do que qualquer outra. Não importa o resultado de sua justificativa, o fato é que neste momento o pirrônico se colocaria além de uma mera suspensão de juízo. A suspensão de juízo é uma atitude que coloca, na verdade, o cético na aporia de cair inevitavelmente numa de duas formas de dogmatismo prático: ou ele simplesmente age recusando-se a qualquer argumentação racional (terá então de aceitar, para poder viver, os costumes e leis de seu povo, etc.) - um determinado tipo de dogmatismo prático - ou ele simplesmente recusa qualquer forma de ação, o que não só lhe impediria de viver, mas terminaria por levar a um tipo de ação não justificada, ou seja, àquela ação própria do decidir-se a não agir - novo tipo de dogmatismo."

Cf. final da nota 31 .

* Sobre a relação entre Pirrorismo e Dialética cf. J. N. Heck, “Ceticismo versus Pirronismo" in: Rev. Sintese Nova Fase v. 23, n. 75, 1996, p. 503 ss.

- Cf. V. Brochard, Los Escéticos Griegos, Buenos Aires, Lousada, 1945, p. 152.

4. Da mesma forma no assim chamado neopirronismo de $O$. Porchat, segundo as suas próprias palavras: "Tendo conhecido de perto a problemática filosófica, tendo longamente meditado sobre o conflito insuperável das filosofias, consciente também do caráter contraditório de qualquer empreendimento que se constituísse como uma filosofia da recusa de filosofar, incapaz de apostar na consumaçăo histórica da filosofia, somente lhe restará o ato heróico da recusa não-filosófica e filosoficamente injustificável (grifo meu)" (Vida Comum e Ceticismo, Sảo Paulo: Brasiliense, 1993, p. 21). Se não ficássemos nesta mera recusa injustificada, deveriamos propor talvez uma "[...] filosofia 
25. Costuma-se contrapor ao ceticismo pirônico o ceticismo dos acadêmicos, ou da Nova Academia, de um Arcesilau ou Carnéades. A importância desta escola é ter percebido justamente 0 caráter inelutável das questões práticas. Carnéades terminará tendo de diferenciar entre verossimil e inverossímil, como forma de encontrar um critério mínimo para regular as ações práticas. Esta adoção de uma espécie de teoria da probabilidade por Carnéades é discutível ${ }^{12}$ mas será considerada nas críticas de Sexto Empírico: para este, os acadêmicos terminariam recusando a epoché , o que resultaria em incorrer em contradições inevitáveis."

Gostaria, no entanto, de opor ao ceticismo pirrônico, enquanto ceticismo parcial, uma outra forma de ceticismo: aquele defendido por Górgias, conforme fragmentos. O ceticismo de Górgias é uma forma de ceticismo integral, radical. Isto porque não há nenhuma esfera em seu argumento que pressuponha um momento dogmático, ao contrário do que ocorria com o ceticismo pirrônico. Os argumentos de Górgias podem ser apresentados em três proposições: 1) nada existe; 2) se algo existe, não é compreensivel ao homem; 3) mesmo sendo compreensível, todavia não é comunicável ou explicável a outra pessoa." Vemos aqui a radicalidade do argumento de Górgias, que termina por abarcar três âmbitos distintos do pensamento filosófico: nível do ser (1⿳亠丷厂 proposição); nivel do conhecimento ( $2^{a}$ proposição); e nível da fala ou da linguagem ( $3^{\mathrm{a}}$ proposição). ${ }^{45}$ Vemos aqui que a teoria do cético é uma teoria da dissociação. Quando Górgias nos diz "nada existe", certamente não recusa o estar dado de certos fenômenos; ele está aqui negando duas das características básicas da existência: a permanência e universalidade das coisas, ou a unidade do real. A teoria cética é uma teoria da dissociação. Se nada é minimamente universal (voltado ao uno, à totalidade) nem permanente, nada é. Mas, se algo é ou existe, não pode ser conhecido, pois cada sentido tem uma função específica e possui um acesso diverso ao real: esta caneta que agora me parece dura segundo o tato, segundo o olhar possui esta forma especifica, mas segundo a audição não só não apresenta forma como não possui caracteristica definidora alguma. Qual destes órgãos dos sentidos me diz o que de fato existe aí fora?* Aqui a teoria da dissociação é aplicada ao âmbito epistemológico. Por fim, se algo existe e pode ser conhecido, não pode ser comunicado.

O ceticismo levado às suas últimas conseqüências se desmente: pois de fato, se nada pode ser comunicado, então pelo menos esta afirmação cética tem de ser comunicada: a teoria da dissociação, que não nos causou nenhuma contradição nas outras partes do discurso cético, chega aqui a um flagrante impasse: a tese do

do reconhecimento do mundo" (id., p. 70): mas o que esta filosofia do "Mundo" poderia ser senão uma nova forma de dogmatismo? $\mathrm{B}$ isto novamente conforme as próprias palavras de Porchat: "Essa filosofia vê o Mundo, então, como presença inexorável que se manifesta e impõe irrecusavelmente. [...] Fato bruto e primeiro, objetividade plena, que se dá imediatamente, numa evidência absoluta e primeira, imune a qualquer dúvida [grifo meu]" (id., p. 68).

Cf. BROCHARD, op. cit., p. 163-164.

Id., ibid., p. 462.

" Górgias, Testemunhos e Fragmentos, Lisboa: Colibri, 1993, p. 31.

${ }^{45}$ É fascinante o modo como este filósofo, nascido acerca de 483 a.C., soube envolver no seu círculo cético aqueles que viriam a ser os assim-chamados três grandes paradigmas do pensamento ocidental: paradigmas do ser, da consciência e da linguagem.

* Cf. as análises de F. Nef, A Linguagem, Rio de Janeiro: Jorge Zahar, 1995, p. 12. 
ceticismo só vingaria se aceitássemos ao menos um nível de unidade/universalidade: aquela unidade da comunicação dós dois céticos que dialogam e aceitam que ao menos a proposição "nada pode ser comunicado" é comunicada. O princípio da universalização, que havia sido negado nos demais momentos do discurso cético, é aqui, ao nivel da fala, reintroduzido.

26. A negatividade cética, quando levada às últimas consequiências, se desfaz. Isto o próprio Descartes já havia percebido em suas Meditações. Mas qual a conclusão que podemos tirar desta aporia do cético? Para confirmar a efetividade - a realização possível - de seu ceticismo, ele terá de assumir a validade do princípio de universalização, o assim chamado Conceito hegeliano, ou ainda a coerência universal (Cirne-Lima). Tanto o Conceito como o principio de coerência dizem o mesmo: deve-se superar as dissociações, as oposições não conciliadas, inerentes ao saber, sob pena de cairmos num impasse. A expressão lógico-formal deste princípio é o chamado princípio de não-contradição. É de se notar que o nosso diálogo com o cético não teve início com a pressuposição deste princípio, mas, pelo contrário, pela recusa da própria atividade de universalização via argumento cético."

27. Mas, justamente por isto, pelo fato de o princípio racional ter sido justificado, e ter mesmo emergido enquanto princípio no próprio processo do ceticismo, é inútil toda a tentativa de imunizá-lo desta esfera negativa. Não podemos dizer: "agora que provamos o princípio, podemos rejeitar de vez o ceticismo e nos retirarmos à segurança do saber absoluto". A justificação só é porque o cético ele mesmo - e não seu opositor - levantou a pretensão de um ceticismo radical; é a atividade concreta do cético - a própria fala do cético, que ao se recusar a comunicar, comunica algo - que leva à justificação do princípio que, destacado desta dimensão concreta, retorna sempre de novo a um mero pressuposto dogmático; por outro lado, o ceticismo radicalizado é justamente a expressão do princípio de universalização, de pretensão de totalidade do Conceito.

" É importante percebermos, aqui, que a conclusão da argumentação do cético com o cético não leva a uma mera tautologia, pois de fato o inicio do diálogo não se deu sob o pressuposto de qualquer principio. Pelo contrário, a argumentação do cético vinha negando a própria possibilidade de qualquer princípio racional. Ao fim do diálogo não chegamos, assim, à repetição de um princípio já suposto, mas pelo contrário a própria constituição do princípio só se dá na conclusão.

18 Princípio é aquela estrutura normativa última em que se sustentam os sistemas racionais. Ora, o Conceito só surgiu como instância última, enquanto princípio, no próprio desfecho da argumentação cética, mas não se colocava deste modo em seu início. No início tínhamos a recusa do cético a qualquer princípio; ao fim, temos o resultado de que a negatividade radicalizada leva à aceitação do Conceito como princípio de universalização, respectivamente unificação, única instância a resistir à atividade cética. Mas, como o princípio emergira na imanência do ceticismo, ele só se constitui como princípio ao incorporar a atividade cética como momento de si mesmo, sua origem irrecusável. Sendo assim, o principio enquanto estrutura normativa contém em seu âmago um momento negativo e contingente, ou, o que é o mesmo, a contradição por insuficiência. Esta contradição aponta sempre para a possibilidade igual de manifestar-se como contradição disruptiva (momento irracional) ou contradição superada (síntese racional). Desta forma, o próprio princípio racional (o Conceito em Hegel) não pode constituir-se na dialética senão como um mero dever ser, uma estrutura não determinante mas reguladora. Sobre a distinção entre estes três niveis de contradição dialética, cf. E. LUFT, Para uma Crítica Externa ao Sistema de Hegel, Porto Alegre: Edipucrs, 1995, p. 82-3-4 e Sobre o §81 da Enciclopédia e o conceito de contradiçăo em Hegel, in: Rev. Veritas, Porto Alegre, v. 41, n. 164, p. 657-669. 
28. Voltando à querela do transcendental e do empírico, qual o lugar desta divisão do saber no argumento precedente? O momento empírico - a ação concreta do cético - e o momento transcendental - o princípio da coerência universal - estão aqui imbricados e um não pode se autonomizar com relação ao outro. Se a ação concreta do cético se autonomiza do princípio, ela se torna dogmatismo - o cético terminará por adotar a suspensão de juizo; se o princípio se autonomiza de sua origem cética ele se torna um mero postulado dogmático. O cético não é a planta, de quem o filósofo pode finalmente se libertar: ele é, muito pelo contrário, o verdadeiro guardião da criticidade do filosofar.

29. O problema fundamental que aparece por fim é: obtivemos aqui, na refutação do ceticismo via o próprio ceticismo, como parecia querer Hegel, uma prova rigorosa do Conceito? Já Aristóteles havia apresentado argumentos desfavoráveis contra a idéia de uma demonstração de princípios: afinal, como demonstrar principios, se o próprio processo de demonstração os pressupõe? A princípio, o que foi feito aqui não é uma demonstração e nem qualquer tipo de prova definitiva: simplesmente realizamos uma atividade do pensar negativa, critica que, enquanto atividade, refutou o ceticismo radical (aquele ceticismo realmente integral, que não se contenta - como o ceticismo pirrônico - com a afirmação de uma práxis dogmática). Mas só o refutou provisoriamente, no âmago de uma radicalização do próprio ceticismo. $\mathrm{O}$ argumento todo é autocondicionado pela própria característica contingente de sua gênese, por ser uma atividade concreta realizada no diálogo efetivo entre céticos. A todo o momento que o parceiro se retirasse do discurso teriamos de recorrer novamente a ele para tornar mais uma vez possivel a justificação do Conceito: trata-se de um processo jamais acabado. Seria insano, neste caso, buscar uma justificação definitiva.

\section{Idealismo Absoluto como Filosofia Crítica 2 - rompendo o dualismo}

30. Devemos nos deter um pouco mais no giro argumentativo realizado ao passarmos da argumentação transcendental para o diálogo entre céticos. A característica básica da argumentação transcendental era a de que toda a sua estrutura se vincava numa separação rígida entre dois niveis da linguagem: fala argumentativa e fala não argumentativa. $\mathrm{O}$ filósofo transcendental simplesmente reintroduzira aqui um velho artifício da tradição que constava justamente em, atrávés de dicotomias fundamentais, procurar garantir de saída um campo da linguagem como fundado em princípios indubitáveis e imune ao ceticismo. 0 dualismo foi sem dúvida o recurso mais utilizado pela tradição para escapar do argumento cético.

Pelo contrário, o diálogo entre céticos é justamente realizado antes da dissociação entre dois niveis da linguagem. Se o cético pressupõe algo, isto é pelo contrário a tarefa de dissolver a certeza de uma unidade última do conhecimento, de uma razão fundada em principios. Enquanto atividade de dissociação, o ceticismo é a recusa do princípio fundamental de toda a racionalidade: o princípio de universalização (respectivamente unificação, como se depreende da etimologia do termo universal: voltar-se ao uno). Este princípio é no fundo a base de grande parte das filosofias do passado: seja na forma de Idéia do Bem em Platão, da 
Substância em Espinosa, do cogito em Descartes, do "eu penso" em Kant ou do Conceito em Hegel, todos estes princípios apontam para a idéia de que há uma unidade fundamental do saber.

31. Se olharmos com cuidado para as filosofias críticas de Descartes e de Hegel, veremos que seu caminho é justamente o inverso. Eles não partem da aceitação do principio e de uma visão dicotômica na tentativa de imunizar o seu argumento da atividade cética. Descartes parte da dúvida: da dissociação de toda a certeza, de toda a unidade possivel do conhecimento. Hegel parte da negatividade da dialética, que dissolve as certezas do entendimento. Estes filósofos realizam aqui um discurso racional, mas não como se sua fala fosse desde sempre conforme a princípios, mas pelo contrário no sentido de que eles buscam inicialmente justificar um argumento cético através da recusa do princípio de universalização. 0 discurso é racional quando busca uma justificação para suas teses e esta justificação não necessariamente está vinculada a certos principios racionais pressupostos: o cético parte, ao invés, da recusa de princípios e nem por isto o seu discurso deixa de ser racional (só deixará de ser efetivamente quando, ao se radicalizar, terminará por ter de aceitar que pelo menos o princípio de universalização resiste à sua atividade negativa).

32. A Lógica hegeliana deve ser entendida como o lugar em que se dará o descenso das teses dogmáticas da tradição metafísica para a criticidade do diálogo ${ }^{\circ}$. O que Hegel faz nesta obra é mostrar que as categorias, supostas por Kant como desde sempre válidas, não se sustentam imediatamente como predicados do Absoluto. Ao querer predicar certa categoria do Absoluto, o resultado é exatamente o inverso do que se esperava: o sentido da categoria se dissolve na contradição dialética. A este momento Hegel havia chamado o negativo racional, ou o momento do ceticismo. Hegel não pressupõe a validade dada das categorias: a dialética visa justamente quebrar este seu caráter de estar dadas: rejeitar a suposição ingênua de que existe de fato um âmbito da linguagem que está desde sempre preservado da criticidade do pensar.

33. Se algum princípio racional deve emergir do discurso dialético, ele só emergerá ao resistir a este momento negativo. O princípio racional - o Conceito, para Hegel - não está dado previamente, como já constituído: ele se dá na imanência da atividade cética e se revelará como aquela única instância que, ao fim de todo o desenvolvimento da Lógica, resiste à negatividade da contradição dialética. Daí por que o Idealismo só pode ser Idealismo Absoluto enquanto Filosofia Crítica: não há outro acesso ao Absoluto senão o caminho negativo da passagem pela - e do suportar da - contradição dialética. Pois, se estipulássemos o Absoluto como dado, já o teriamos diferenciado de algo que não é o Absoluto, e esta dicotomia permaneceria não problematizada, ou seja, cairiamos no dogmatismo. De saída não temos de modo algum dois âmbitos da linguagem: temos simplesmente o campo conflituoso e incerto do diálogo, a atividade crítica do pensar, que se lança contra todas as afirmações pretensamente inquestionáveis. Aquele que resistir ao turbilhão do ceticismo, este é o filósofo.

4. Cf. sobre isto as teses de Rüdiger Bubner, op. cit., particularmente p. 88ss. 
34. Mas, como já haviamos visto mais acima, o próprio Hegel - como Descartes - foi incapaz de problematizar as verdadeiras conseqüências deste novo modo de tematizar a justificação dos princípios. Ele acreditou que o momento negativo-racional poderia ser superado pela face especulativa pura da Idéia Absoluta: que o Conceito poderia liberar-se de sua própria face negativa, realizando-se plenamente na Idéia. Sua concepção de sistema fechado termina por incompatibilizar-se com sua própria concepção de dialética, o círculo do Conceito refuta a dinamicidade da contradição.

35. Na verdade, após a imersão no ceticismo, e com a radicalização do momento negativo-racional, não chegamos a nenhuma demonstração a priori de princípios, a nenhuma certeza inabalável ou última: o que alcançamos é apenas o resultado provisório, condicionado pelo ato concreto do diálogo com o cético, de que o próprio ceticismo leva ao fim à aceitação do Conceito como princípio racional. Ou seja, voltamos a encontrar os limites de uma razão que se pretende de totalidade ou absoluta: ao nos lançarmos no campo do ceticismo, ao pretendermos abarcar com a razão a empiricidade inerente ao diálogo concreto, terminamos enfraquecendo o nosso conceito de racionalidade. A mesma racionalidade que se expande para abarcar todo o saber (que não se refugia na certeza de um "transcendental" imunizado do ceticismo) é aquela que se mostra como racionalidade fraca.

36. Descartes teve plena consciência dos resultados que se atinge com a chamada "justificação negativa" de princípios, mas não soube levar até o fim as suas conclusões. $O$ resultado do argumento da dúvida em Descartes não é a certeza do eu penso e sim do estou pensando. Parece claro que o argumento só resiste à crítica cética enquanto está se dando a própria atividade do pensamento. De fato, quando a atividade deixa de ocorrer, ou mesmo enquanto o pensamento não se debruça sobre si mesmo enquanto ato de duvidar, o ceticismo ressurge com toda a sua força. A argumentação cartesiana não nos autoriza, portanto, a uma suposta refutação definitiva do cético: pelo contránio, todo o argumento da dúvida só se sustenta na imanência e universalização do próprio ceticismo, e só é capaz de superar o ceticismo sempre provisoriamente. O próprio Descartes, como dizíamos, teve consciência disto: nas Meditações, ele nos diz: "Outra coisa é o pensar; e verifico aqui que o pensar é um atributo que me pertence. Eu sou, eu existo: isto é certo; mas por quanto tempo? A saber, por todo o tempo enquanto penso (grifo meu); pois poderia ocorrer, se eu deixasse de pensar, que deixasse ao mesmo tempo de ser ou de existir". ${ }^{\circ}$ Mas o próprio Descartes terminará hipostasiando o cogito, tratando-o como princípio inquestionável e imutável de um sistema dedutivo.

37. Na verdade, só não recaímos numa nova forma de dogmatismo - que provavelmente terá a forma de um novo dualismo: como aquele que Hegel inevitavelmente teve de reintroduzir entre a necessidade do Conceito e a contingência da natureza, ou entre a "pureza" transcendental da Lógica no círculo da Idéia e a empiricidade da Fenomenologia - se aceitarmos o fato de que, ao justificarmos o Conceito na imanência do ceticismo, através de sua radicalização, o resultado não

so Descartes, "Meditations", in: Ouevres de Descartes, Paris: Vrin, 1973, 22, p. 21. 
será aquele de uma fundamentação definitiva do princípio $0^{61}:$ a contradição dialética não pode ser aniquilada no interior do sistema. Toda síntese da Lógica é provisória, e aquela síntese final que se dá na circularidade do pensamento que se pensa a si mesmo não é a comprovação definitiva de um momento extra-empírico último. Pelo contrário, o que a circularidade da idéia nos prova é justamente que a tentativa de autonomizar a Lógica da Fenomenologia se faz em vão, que o ato de pensamento só existe na constante superação de instâncias dogmáticas e na instauração de sínteses provisórias, ou seja, que o circulo só se mostra como boa circularidade enquanto se põe no processo de superação de contradições (que, portanto, jamais são eliminadas totalmente); caso contrário, terminaria no eterno retorno vazio sobre si mesmo, numa mera tautologia. Estas afirmações equivalem a dizer que reside um momento de empiricidade ineliminável na Lógica hegeliana, ${ }^{, 2}$ o que só vem confirmar a tese de todo este artigo de que a cisão entre os momentos empírico e transcendental é estranha ao pensamento dialético.

38. Mas talvez a diferença mais importante entre a Filosofia transcendental de Kant e o pensamento dialético é que, para o primeiro, os limites da razão são sempre externos ${ }^{50}$ - a coisa em si - ao passo que, para o segundo, eles são imanentes.

61 Como não concordar aqui com as palavras de O. Porchat: "Essa coerência das grandes filosofias me seduzia. [...] Mas a justificação que cada uma propunha de seu próprio sistema não me pôde persuadir. Porque eu conhecia a razão das outras. E descobrira que nenhuma fundamentação era absoluta [grifo meu], nenhuma legitimação era definitiva" (op. cit., p. 30)?

52 Um dos comentadores de Hegel que viu isto com a maior precisão, e soube vincular o momento de empiricidade ao caráter ineliminável da contradição dialética, foi G. R. G. MURE, em sua obra A Study of Hegel's Logic, Oxford: Clarendon, 1967: "Não existe dialética que não tenha a contradição por sua origem, e nenhuma contradição que não tenha o seu momento empirico" (p. 343). Não è aqui o contexto de provar esta tese, mas acho possivel defender a tese de que o próprio conceito de contingência (base do conceito de empírico - oposto a transcendental ou necessário em Kant) esteja fundado na contradição dialética enquanto contradição por insuficiência que contém por igual a possibilidade de manifestar-se como contradição disruptiva ou contradição superada (ou conciliada na sintese).

๘ É este caráter de condicionamento externo que tem de ser superado pelo Idealismo, se este quer ser Idealismo Absoluto. Este elemento de exterioridade é, para Hegel, elemento de contingência, a ser afastado e anulado na necessidade da autoposição da idéia absoluta. Poderiamos pensar, no entanto, em um modo diverso de superação da exterioridade: a interiorizaçăo racional de elementos contingentes como condição de possibilidade do elevar-se da razão à totalidade, de sua ampliação como filosofar. Esta ampliação ao mesmo tempo resolve a dicotomia entre eu empírico e transcendental - mostrando estes opostos como correlativos - e enfraquece o conceito de racionalidade: a dialética é uma forma de racionalidade que, justamente por elevar-se ao nível de totalidade - por incorporar em si momentos de contingência - modifica-se de ser para dever ser, de necessidade forte para necessidade fraca (Cf. os argumentos de Cime-Lima, particularmente em suas obras Sobre a Contradição, op. cit., e Dialética para Principiantes, op. cit.). O maior problema de Hegel foi justamente ter proposto ao mesmo tempo uma ampliação do conceito de racionalidade e a confirmação da estringência da lógica a ele vinculado. Já para Aristóteles a dialética viria suprir justamente a falta de uma racionalidade capaz de dar conta da totalidade do saber. Mas a ampliação dialética da racionalidade se dá, no filósofo grego, exatamente através do reconhecimento da insuficiência/falta do saber. Segundo P. Aubenque: "Em oposiçảo a Hegel, o caráter dialético permanece para Aristóteles não o sinal de uma superioridade, mas de uma falta (Mangel)" ("Hegelsche und Aristotelische Dialektik", in: M. Riedel (org.) Hegel und die antike Dialektik, Frankfurt am Main: Suhrkamp, 1990, p. 221). Sobre a dialética como racionalidade fraca, cf. também as teses da chamada Escola de Bruxelas, cujo representante principal é C. Perelman (cf. Retóricas, Săo Paulo: Martins Fontes, 1997, e Tratado da Argumentaçăo, São Paulo, Martins Fontes, 1996). 
Não é porque existe o ceticismo, como a planta calada e intocável além do sistema fechado da Razão Pura, que a atividade racional é limitada: é porque a razão só se eleva ao nivel de totalidade - porque o Idealismo só é Absoluto - ao introjetar em seu âmago o ceticismo que as pretensões de uma fundação última definitiva se desfazem e a razão se mostra enfraquecida.

39. Com isto, se ao filósofo restou simplesmente a atitude injustificada de considerar o cético uma mera planta, esta suprema ironia, ao cético poderiamos conceder o riso, o deleite da jovem trácia que alertava para os riscos do abismo criado pelos mais antigos filósofos entre duas esferas do pensar: a separação entre empírico e transcendental; este abismo cavado com afinco, na esperança de libertar definitivamente a Filosofia do ceticismo, terminou por engolfar o seu próprio criador: a Filosofia se tornara dogmatismo, e o filósofo estava aí deitado no fundo do poço, necessitando urgentemente da trácia, que corria para socorrê-lo. 